\title{
The Difficulty of
} Historical Work in the Nineteenth-Century Museum and the Thackeray Novel

\author{
DEHN GILMORE
}

\section{T}

The Newcomes (1853-55), his famously "baggy" novel about the development of would-be painter Clive Newcome, William Makepeace Thackeray is rarely economical in his expression. Yet late in the lengthy work a notable exception occurs, and as he proclaims his efforts at offering "true" history (via the lips of his chronicling persona, Pendennis), Thackeray approaches a concise delineation of some potential outcomes for historical practice. In the words of Pendennis, the writer-editor of a history inevitably makes choices; he "dresses up the narrative in his own way," or he "commits blunders, which the critics will discover." Accordingly, the historian's craft seems destined to be just that-a complex and multifarious labor of production and reconstruction-and proximity, whether

\footnotetext{
Nineteenth-Century Literature, Vol. 67, No. 1, pp. 29-57. ISSN: 0891-9356, online ISSN: 1067-8352. (C) 2012 by The Regents of the University of California. All rights reserved. Please direct all requests for permission to photocopy or reproduce article content through the University of California Press's Rights and Permissions website, at http://www.ucpress.edu/ journals/rights.htm. DOI: $10.15^{2} 5 /$ ncl.2012.67.1.29.
} 
to accuracy or to the past, must become a matter of calculation and degree:

... when you read such words as QVE ROMANVS on a battered Roman stone, your profound antiquarian knowledge enables you to assert that SENATVS POPVLVS was also inscribed there at some time or another. You take a mutilated statue . .., and you pop him on a wanting hand, an absent foot, or a nose, which time or barbarians have defaced. You tell your tales as you can, and state the facts as you think they must have been. ${ }^{1}$

This vision of writing history can seem most distinctive for its diffidence. Yet actually, even more notable is the way in which Thackeray's emphases make him typical of his artistic era. Here Thackeray proposes three different possibilities in handling history's objects and records. In what follows I suggest that both Thackeray's enumeration of these possibilities and his use of an artifactually laden language to frame them signify; I will show that his tri-partite conception and his phrasing of it place Thackeray right in the middle of a debate about historical preservation and representation that was central to the mid nineteenth century's broad artistic sphere.

In Thackeray's diagnosis, the would-be historian can content himself with mere "knowledge" and "assert[ion]"; this is a model of practicing history in which to venerate the past is to keep an accepted distance from that same site. But to practice history could equally involve reaching beyond mere respect and preservation toward an active effort at a restoration of what was, and, with a more brazen advance, two more exaggerated possibilities for historical practice emerge. Push toward restoration and a historian might attain something close to full-on resuscitation; "pop . . . on" a statue's "wanting hand," and maybe he could undo the ravages and "deface[ments]" of time, to experience the world as his forbearers did. But he could also engender a potential for obliteration or total obfuscation, his "restoring" actions could really consist in "blunders," and with them he might erase exactly what he

\footnotetext{
${ }^{1}$ William Makepeace Thackeray, The Newcomes: Memoirs of a Most Respectable Family, ed. Peter L. Shillingsburg, 2 vols. in 1 (Ann Arbor: Univ. of Michigan Press, 1996), I, 221. Further references are to this edition and appear in the text.
} 
tried to return to-to make the flipside of exhilarating temporal return a danger of destruction. Nominally pausing to reflect on his narrative procedure (and success), Thackeray ends up inscribing the terms of a fervent argument that raged in the midcentury's worlds of visual and verbal art, about how best to maintain the past for an ever-growing public. He inscribes, at the same time, a double nature to his investment in this debate; he reveals how his work as a historical novelist was consistently shaped by his engagement with a multifaceted sphere of visual culture-and especially by his interest in the site of the museum.

In what follows, I consider visual and verbal institutions together, and I trace how the National Gallery's and British Museum's tangible, mid-century experiences with preservation, restoration, and "blunder" influenced Thackeray's efforts to reimagine the novel's relation to history. The starting grounds for my investigation are some very specific features of Thackeray's vocabulary of "battered" stones and "mutilated statues." Yet, as I uncover local sources for this phrasing in angry shouts reverberating through gallery hallways, I map a shared set of large-scale and more abstract intellectual concerns. Two of the most important approaches that the Victorians took to remonstrating with the past-their representation of it in historically engaged fiction and their institutionalization of its relics in museums-shared a fundamentally dual aim: both the historical novel and the museum sought to preserve history's facts, details, and objects (and with these, its spirit); they both sought in turn to offer a meaningful arrangement of these elements (the novel by narrativizing and describing them, the museum by grouping and displaying them). ${ }^{2}$ At the same time, the historical novel and the museum shared a mid-century moment of crisis, and Thackeray's actual, physical location in the British Museum when he wrote a historical novel like The History of Henry Esmond (1852) proved highly purposive. ${ }^{3}$ In trying to reconceive the relation between

\footnotetext{
${ }^{2}$ Neither the National Gallery nor the British Museum had adopted a consistent chronological hanging system in Thackeray's day, and often the placement of a given work was determined by its size or date of acquisition. As a result, to walk down a Gallery hallway or into a Museum room was unlikely to engender a sense of narrative or development.

${ }^{3}$ See John Sutherland, "Introduction," in William Makepeace Thackeray, Henry Esmond, ed. Sutherland (New York: Penguin Books, 1985), pp. 8-9.
} 
history and narrative, Thackeray turns out to have looked beyond historical painters-his logical analogs in his "sister" branch of the arts, as artists, like him, who tried to imagine what the past had been like (he looked also to those who touched history more directly)to restorers and curators, to people who physically tried to bring the past back to life, and ultimately we will see how Thackeray's sense of his own productions' potential, but also their failures and limitations, were crucially informed by this second regard.

Leading up to the $185^{\mathrm{os}}$, the decade in which Thackeray would make his most sustained investigation into a historicized fiction, the museum's confrontation with issues of preservation and transmission came to be dramatically forced, in a way designed to pique (and maybe to torture) the imagination. Increasingly, the museum was working for a larger and more diverse audience than ever before, yet increasingly too this audience took a toll on the works it had come to see. As museum workers sought sometimes to stanch and sometimes to repair the resulting damages, their actions made the museum a crucial site for the posing of questions about how best to uphold and arrange history and its effects. The museum thus also became a crucial stage on which different ideas about the present's relationship with the past were physically rehearsed; it became a crucial source of terms and ideas for those, like Thackeray, who were interested more broadly in the problem of history's presentation. Indeed, commentators on the museums' efforts at protection, cleaning, and selective "retouching" anticipated Pendennis as they divided into three camps, and there were those who focused on how a hands-off approach was best ("we must make up our minds to put up with a certain amount of dirt, and study the works of departed genius through the warm haze of time"); those who thought that more actively restoring pictures could summon in them "the purity and freshness in which the various great painters sent them forth from their hands to the world"; and then those, much to the contrary, who were fixated on the idea that "scouring" the museums' works was tantamount to a "flay[ing]" violence, and that any cleaning was tantamount to a desecration.

\footnotetext{
${ }^{4}$ See [A Tory in Art], "National Gallery: To the Editor," The Times, 28 December 1852 , p. 3; [Anon.], "Picture Cleaning in the National Gallery," Art-Journal, 1 January 1853, p. 30; and William Coningham, "To The Editor," The Times, 8 December 1846, p. 7 .
} 
In 1853 , as he finished The Newcomes and wrote Pendennis's discourse, Thackeray obviously drew from previous literary work when he employed his narrator to articulate the possibilities inherent in historical work; by the year of that novel's publication, he had read and studied Thomas Babington Macaulay, written parodies of others' historical novels for Punch, written novels of his own that engaged heavily with history, and produced one novel, Henry Esmond, which was manifestly a historical workand one that I will treat at length in the final part of this essay. In all of these ways, Thackeray came by his understanding of historical approach from within the world of letters. But Thackeray's literary world was a space that overlapped heavily with the world of the museum, and his work as a practicing art critic, his tendency to comment on the National Gallery, and his promotion of the British Museum as a place to meet with "a heart full of grateful reverence" and a place to be gloried in as a specifically "English birthright," were equally influential conditioning forces behind the manifest ambivalence of Pendennis and Thackeray's sense of the historian's project. ${ }^{5}$ In the midst of the art world's swirl of confusion and agitation, Thackeray's lifelong engagement with that world took on a special significance, and as he weighed his options as to how best to approach and present the site of history, debates about art and artifact significantly shaped his deliberations and his articulation of them.

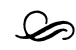

The viability of both the historical novel and the public museum were under question in the decades leading up to and encompassing Thackeray's publication of such historically engaged fiction as Barry Lyndon (1844), Vanity Fair (1847-48), The History of Henry Esmond, The Newcomes, and The Virginians (1857); indeed, the health of each form for historical presentation

\footnotetext{
${ }^{5}$ Thackeray chiefly addresses the British Museum's library in these remarks, though he has recourse in the text from which they are taken to the whole domed structure of the British Museum. Writing a tribute obituary of Macaulay (and Washington Irving), he compared the dome of the British Museum to the dome of Macaulay's head-both repositories, for him, of infinite wisdom. See [William Makepeace Thackeray], "Nil Nisi Bonum," Cornhill Magazine, 1 (1860), 133.
} 
seemed to many observers to be in crisis. When it came to the historical novel, the form might be said to have had something of an uncomplicated commercial heyday and formal practice from the teens and twenties of the nineteenth century-when, as John Bowen suggests, "the novel" as a larger category was "dominated, overawed almost, by the achievement of [Walter] Scott" and his series of historical works-through the 183 os, when the popularity of writers such as William Harrison Ainsworth, Edward Bulwer-Lytton, and G.P.R James was at its peak. ${ }^{6}$ But by the time of the mid to late 184 os there arose what Stephen Bann has called an "ironic and fractured historical discourse" among a wide class of writers and artists, and this counteracted a "perhaps excessive faith in historical recreation which had characterized the immediately previous period." "7eorgy Lukács places this turn at or about 1848 , as driven by the challenge that year's events posed to a sense of large-scale historical progress and mission; most scholars follow his lead. ${ }^{8}$ As Nicholas Rance writes, "The Revolutions [of 1848 ] seem to have accelerated, without initiating, a tendency among English writers to detach themselves from the historical process." ${ }^{9}$ Indeed, from within the nineteenth century itself there was an incipient self-recognition that a new formal difficulty had arisen, and in 1846 George Henry Lewes drafted an influential critique of what he called the "bad and false history," the "useless, or worse than useless handling of past times" to be found in the "bastard species" that was the historical romance. ${ }^{10}$ Throughout the 184 os Thackeray wrote a series of Punch-bound parodies of historically invested writers like Bulwer-Lytton, G.P.R James, and

\footnotetext{
${ }^{6}$ John Bowen, "The Historical Novel," in A Companion to the Victorian Novel, ed. Patrick Brantlinger and William B. Thesing (Oxford: Blackwell, 2002), p. 246.

${ }^{7}$ Stephen Bann, The Clothing of Clio: A Study of the Representation of History in Nineteenth-Century Britain and France (Cambridge: Cambridge Univ. Press, 1984), pp. 126 and 115 .

${ }^{8}$ See Georg Lukács, The Historical Novel (1962; Lincoln: Univ. of Nebraska Press, 1983), pp. $172-83$.

${ }^{9}$ Nicholas Rance, The Historical Novel and Popular Politics in Nineteenth-Century England (London: Vision Press, 1975), p. 13.

${ }^{10}$ George Henry Lewes, "Historical Romance:-The Foster Brother, and Whitehall," Westminster Review, 45 (1846), 20, 19.
} 
James Fenimore Cooper-perhaps, as his biographer Gordon N. Ray suggests, "play[ing] a part in bringing historical fiction to th[e] low estate" it was in by the time Henry Esmond debuted."11 And as of the fifties, a publisher would tell Anthony Trollope: "Whatever you do, don't be historical; your historical novel is not worth a damn." 12 Increasingly, readers and writers of historical fiction asked the same question that Ainsworth put in the mouths of Henry Esmond's audience: "what . . . have we, who live in the middle of the nineteenth century, to do with the manners of those who "flourished' a hundred and fifty years ago?"13 And if there was a transhistorical connection to be made, still audience and authors questioned whether there was any way to get at real historical truth in fiction, or whether an attempt to find it should be abandoned altogether-whether, as Lewes wrote, "no-knowledge" might perhaps be "better than mis-knowledge" ("Historical Romance," p. 20).

Over at the museum, the onset of a troubling revaluation had perhaps been longer in coming, and from the founding of the National Gallery in 1824, and the developing democratization of the British Museum in the 181 os and 1820 , both museums had provoked anxieties about their conservatorship of the past. Their always too-small physical plants, and subsequent tendency to crowd and jumble their contents, drew consistent fire, and in 1838 Thackeray voiced a common feeling when he criticized the National Gallery's building variously as "a little building like a gin-shop" and as "a pigmy abortion." ${ }^{14}$ But the 184 os were a time of new or especial crisis, and it was then that the museums' failures took on a more emergent, physical character.

Between $1827-28$ and $185^{1}$, the British Museum saw attendance spike from 81,228 visitors to more than a million per year; from 1830 to 1840 , the National Gallery's visitor roll rose from

\footnotetext{
${ }^{11}$ Gordon N. Ray, Thackeray: The Age of Wisdom, I $847-1863$ (New York: McGraw Hill Book Co., 1958), p. 177.

${ }^{12}$ Anthony Trollope, An Autobiography, ed. Michael Sadleir and Frederick Page (New York: Oxford Univ. Press, 1950, 1980), pp. 110-11.

13 [William Harrison Ainsworth], "Esmond and Some Other Novels," New Monthly Magazine and Humorist, 96 (1852), 483 .

${ }^{14}$ [William Makepeace Thackeray], "Strictures on Pictures," Fraser's Magazine for Town and Country, 17 (1838), 759 .
} 


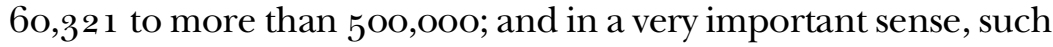
popular success became a great threat to the museums' preserving missions. ${ }^{15}$ It was one thing for museums to fail on the score of accommodating or arranging their contents, but it was another entirely for them to seem to destroy the very works they were charged with guarding - and yet in the 1830 os and 1840 os this was precisely what the museums were accused of. Their urban situation, and particularly the National Gallery's Trafalgar Square site near "several large chimneys," already rendered their works susceptible to what "A Lover of the Fine Arts," writing in to the Times, named a "dirtying effect"-something that built up within just a few years. ${ }^{16}$ But add in the result of what Gallery keeper John Seguier called the "effluvia" of a new mass of visitors (some of them none too clean, as commentators were fond of pointing out), and the art works were in mounting physical peril. ${ }^{17}$ The concern of "A Citizen" was representative, as per his pseudonym, when he fretted in The Times: "Now, surely, this state of things should not be permitted ... it is fatal to the pictures, which are

${ }^{15}$ Figures for the British Museum are from Richard D. Altick, The Shows of London (Cambridge, Mass.: Belknap Press of Harvard Univ. Press, 1978), p. 454; and J. Mordaunt Crook, The British Museum (New York: Praeger Publishers, 1972), p. 196. Figures for the National Gallery are from Janet Minihan, The Nationalization of Culture: The Development of State Subsidies to the Arts in Great Britain (New York: New York Univ. Press, 1977), p. 52. In 1824, the National Gallery's first year, it had enforced somewhat draconian admissions policies and hosted just over 24,0oo visitors between May and November (see Felicity Owen and David Blayney Brown, Collector of Genius: A Life of Sir George Beaumont [New Haven: Yale Univ. Press, 1988], p. 214). But between 1830 and 1835 its attendance figures more than doubled (from 60,321 visitors per year to 127,268) (see Henry G. Clarke, The National Gallery: Its Pictures and Their Painters: A Hand-Book for Visitors [London: Clarke and Wilson, 1842], p. v), as its fame grew, and by the early $184 \mathrm{os}$, with the museum finally moved from the small house where it was originally housed to a larger space at Trafalgar square, the abolition of a requirement that admission be arranged in advance, and the opening of its doors three days a week to give the working classes opportunity to visit, its numbers soared.

${ }^{16}$ [A Lover of the Fine Arts], "The National Gallery: To the Editor," The Times, 11 March 1833 , p. 3. In $185^{\circ}$ the Athenceum noted a report by the Select Committee: "several large chimneys, particularly that of the baths and washhouses and that connected with the steam-engine by which the fountains in Trafalgar-square are worked, from which great volumes of smoke are emitted" ([Anon.], "The National Gallery," Athenceum, 23 November 185 o, p. 1,224).

${ }^{17}$ See David Robertson, Sir Charles Eastlake and the Victorian Art World (Princeton: Princeton Univ. Press, 1978), p. 95. 
rapidly decaying." ${ }^{18}$ Meanwhile, one of the day's most prominent art historians, Gustav Waagen, had his own grim take on the fact that the museum had become what Charles Kingsley called "almost the only place ... where the poor and the rich may meet together." 19 Waagen wrote in the Art-Jourmal that he found the National Gallery to have often "all the appearance of a large nursery, several wet-nurses having regularly encamped there ...; not to mention persons, whose filthy dress tainted the atmosphere"; then he worried that "the exhalation produced by ... any large number of persons, falling like vapour upon the pictures, tends to injure them." 20

Various solutions to counteract the new threat of the crowd were quickly tested. The British Museum's elitist director pursued an unofficial policy of discretionary visitor exclusions and undertook selective scourings, while the National Gallery began a series of picture cleanings. But any notably classist skittishness was met with ire; exemplarily, on Boxing Day of 1846 the Museum claimed a shortage of guards and a fear of overcapacity to shut its doors to close to twenty thousand workers, but railed W. J. Fox (and note the overlap of his artifactual language with Thackeray's Newcomes nose-less imaginings): "Our rulers do not know the people.... They fear to trust them.... They anticipate a multiplication of statues with noses broken off, pictures with eyes scratched out and unique vases smashed to atoms." ${ }^{21}$ Then cleanings at both museums prompted an even more enduring scandal. The ad hoc methods of conservation tried out in organized cleaning campaigns in $1846,185^{2}$, and (at the British Museum) $185^{8}$ had the potential to produce disaster-hardly surprising inasmuch as they might consist of polishing pictures with a handkerchief, washing

18 [A Citizen], "To The Editor," The Times, 30 August 1844, p. 5 .

19 [Charles Kingsley], "The British Museum," in Politics for the People (London: John W. Parker, 1848 ), p. 183 . Kingsley is speaking here about the British Museum; given that institution's relatively slower path to inclusion, he might more aptly have been speaking about the Gallery.

${ }^{20}$ Gustave F. Waagen, "Thoughts on the New Building to be Erected for the National Gallery of England," Art-Journal, 1 May 1853, p. 123 .

${ }^{21}$ W. J. Fox, "The British Museum Closed," Howitt's Journal, 1 (1847), 29-31; cited in Frederick N. Bohrer, "The Times and Spaces of History: Representation, Assyria, and the British Museum," in Museum Culture: Histories, Discourses, Spectacles, ed. Daniel J. Sherman and Irit Rogoff (Minneapolis: Univ. of Minnesota Press, 1994), p. 202. 
them with water, or "removing the superficial dirt and varnish unequally" to effect work "rendered violent in light and shade and false in colour" (A Tory in Art, "National Gallery: To the Editor," p. 3). By the middle of the century there was at least as much of an outcry over efforts to clean the works as there had been over their disrepair. The historical novel might not be "worth a damn"; in talking about the museum, people had taken to cursing.

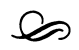

An author like Bulwer-Lytton, who had risen to fame as a writer of historical romances, could deal with a culture that was increasingly skeptical of historical writings by turning to the contemporary scene for his subject (as he did after he published his last romance, Harold, in 1848). A reader like Lewes, who believed that the "flimsiest of novels" was preferable to the "abortion" that the "false imagination" of history produced, could pick up that "flimsy" work, or he could recur to history done right (perhaps some Scott?). Clearly readers did make such choices, and the advice given Trollope by his publishers is a reminder. For those whose charge and quarry were Tintorettos and one-of-a-kind statues, however, there was no such set of options, and the recognition of this limit made what many saw as the museums' "worse than useless handling" of history seem all the more galling and unforgivable. Where many novelists gave up, the museums had to continue, and as they did so, to many onlookers things seemed ever to be getting worse.

In approaching their mission, one alternative that the museums had would of course have been to act conservatively, and simply to try to safeguard their collections or to prevent their further damage. The "Lover of the Fine Arts" who decried the "dirtying effect" of the National Gallery's urban location was one of many people-including Anthony Trollope-to call for the Gallery's relocation to the countryside as a protective move. ${ }^{22}$ The British Museum's attempted closures represented a bid to keep its

\footnotetext{
${ }^{22}$ See Anthony Trollope, The New Zealander, ed. N. John Hall (Oxford: Clarendon Press, 1972), pp. 204-5.
} 
contents safe while they remained in the city. Henry Cole, a great proponent of art for the people, testified before the British Museum Committee in 1860 that "the mere exhibition of pictures to great multitudes exposes them to accidents which would hardly be dreamt of," and that he had "come to the conclusion that pictures within reach must be put under glass." ${ }^{23}$ All of these positions were fundamentally hands-off.

Once the cleaning campaigns began, however, there was something of a rhetorical shift, and though many museums still worked on the project of protective maintenance, it was "restoration" cast either as glorious recuperation or as violent terror that came to capture the public imagination and to dominate the public discourse. In the camp that supported and delighted in the cleaning campaigns, the washing of paintings, the scrubbing of statues, and the retouching of canvases were all cause for celebration, because they all betokened the possibility of a return to the art works' original or "authentic" states. Many thought along the lines that Pendennis would eventually sketch out in The Newcomes, that it was to the good if "you take a mutilated statue ... and you pop him on a wanting hand, an absent foot, or a nose, which time or barbarians have defaced"; they thought the wear and tear of years (and uncouth viewers) could be overcome, and something that was lost could be regained. A writer in the Athenaum allowed that some works by Claude had been roughly handled during the cleaning process and made to "look somewhat crude," for instance, but he was confident that "this crudeness, to our thinking, is only a temporary injury, and that a few years will mellow them into a better tone than they have possessed within the memory of man." ${ }^{24}$ The Art-Journal then was particularly pleased, and in $185^{1}$ it argued: "The [cleaned] pictures ... are now seen with the purity and freshness in which the various great painters sent them forth from their hands to the world" ("Picture Cleaning in the National Gallery," p. 30). What it believed was stripped off was not a rich mantle conferred by history, but rather a gross

\footnotetext{
${ }^{23}$ Henry Cole, quoted in [Anon.], "Fine-Art Gossip," Athenceum, 8 September 186o, p. 330 .

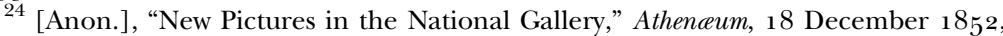
p. $1,397-98$.
} 
quotidian buildup of grime, and, not incidentally, the Art-Journal elsewhere claimed: "The picture-restorer, like the restorer of human bodies, has the pride and excitement of his art." ${ }^{25}$ Here was "preservation" defined as propulsive time-travel; here truly was the hand "popped on"-Thackeray's thought-experiment vis the "mutilated statue" literally tried out.

But for many other commentators such return was unimaginable, and countering those who perceived the cleanings as acts of repair, there were those who saw them instead as wreaking disfiguration, and who decried them as the worst kind of what Pendennis might have called "blunders." Any touch applied to a master's canvas or statue might undermine such a work's claims to "purity" and "pristine freshness" and was "inadmissible," as "Verax" claimed, since "great works are interesting and valuable for those parts only which can be relied upon as genuine." ${ }^{26}$ Restoration was likely to lead to "metamorphoses so complete that the original painters themselves could not recognize their own performances." ${ }^{27}$ Opponents of the Gallery's cleanings quickly spotlit a series of erasures and (literal) defacements they believed the museum's "scourings" to produce. And Times correspondent "Pittor" found all the cleaned works in "absolute ruin." 28 Morris Moore worried: "In the 'St. Bavon' the features . . . have been almost effaced from some of the heads, which now look like

\footnotetext{
${ }^{25}$ [Anon.], "The Report on the National Gallery," Art-Journal, 1 November 1857 , p. 330. The Art-Journal's pleasure had much to do with what it conceived as a set of important aesthetic stakes. To its eye, many had long mistakenly attributed the brown tint of Old Master canvases to their august lifespans, rather than as a mark of modern glazing or dirty modern conditions; it was thus assumed that Old Master paintingsand then, by somewhat illogical extension, new works of any quality-had to be brown-hued if they were worth anything. But the cleanings, according to the Art-Journal, potentially changed this thinking. Finally to be overcome, in its view and that of its sympathizers, was an ill-conceived preference for "the liquorice juice, the dirty veil, the media of chicanery and fraud upon which the 'trading' in works of ancient Art is alone based and conducted" - and happily tossed out, too, might be a whole aesthetic sense, as it satirically wrote: "Skies must be of a dirty grey ..., and flesh tints must either resemble dirty leather or appear covered with brown spots, indicative of a recent virulent corruption," even in modern paintings ([Anon.], "National Gallery-the Brown Mania," Art-Journal, 1 February 1853, p. 66).

${ }^{26}$ [Verax], "The Purchases of the National Gallery: To the Editor," The Times, 19 November 1846 , p. 5 .

27 [Anon.], "Our Weekly Gossip," Athenceum, 9 November 1844, p. 1,024.

28 [Pittor], "The National Gallery: To The Editor," The Times, 20 December 1852, p. 7.
} 
repulsive excrescences of badly imitated or diseased flesh." 99 Punch chimed in when it rued the fate of "Poor 'Susanna' [in Guido Reni's altarpiece] [who] has had her eyes nearly torn out with the sharp bristles of a scrubbing brush"; ${ }^{30}$ in the violent language used here, we see how museum staff members get cast, Pendennis-like, as defacing "barbarians." Then criticisms erupted, even from the side of those-something of a minority-who could be induced to admit that some of what had been erased was something beside the work of the Old Masters. "A Tory in Art" recognized that some of what the Gallery's cleanings stripped away was modern soot, contemporary "effluvia," and recent varnishingbasically all forms of filth or impurity. But still, he wrote:

... we must make up our minds to put up with a certain amount of dirt, and study the works of departed genius through the warm haze of time. ... What is history but a vague old picture with the dirt on? . . . A curly wig does not make the old face look young, and a cleaned old picture is but a battered beau trying to vie with his gay great grandsons at the other end of the building. ("National Gallery: To the Editor,” p. 3)

To "restore" works might not lead to violent "eyes torn out," images "flayed," and "flesh" "diseased," but even if it produced merely the embarrassment conjured by the image of an aging lothario, it was still most definitely a practice to be resisted forcefully.

The tension between those who thought it was better to see works denuded of time's deposits (whether ancient or modern), in what was touted as "their original condition of colour, as completed by the great masters" ("Picture Cleaning in the National Gallery," p. 3o), and those who worried, like a Times-writing "Artist," that as the cleaning continued a majority of the works "supposed to be by the "old masters" "would "consist of the reparations, ill executed, of modern picture cleaners," was a tension that hung in the air, even as the museums' picture cleanings proceeded. ${ }^{31}$ And

\footnotetext{
${ }^{29}$ Morris Moore, "Revival of Vandalism at the National Gallery: To the Editor," The Times, 29 November $185^{2}$, p. 8 .

${ }^{30}$ Quoted in Richard Altick, Punch: The Lively Youth of a British Institution, I84I-I85I (Columbus: Ohio State Univ. Press, 1997), p. 671.

31 [An Artist], "Picture Cleaning: To the Editor," The Times, 24 December 1852 , p. 6.
} 
speaking about the Gallery in the voice of his fictional alter-ego, art critic Michael Angelo Titmarsh, Thackeray anticipated something of this larger cultural ambivalence, if some years before the most serious cleanings were fully under way: "Since the old pictures have got their new gallery, and their new scouring, one hardly knows them," he wrote ("Strictures on Pictures," p. 759). It was easy to lose the "old" with the advance of the "new," and for what you thought you "kn[e]w" to come under threat from too close an approach.

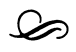

The worries about the historical record and historic objects that the museums engendered were clearly resonant well beyond the walls of keepers' meeting rooms, and the museums' woes ultimately stimulated an official governmental response. A series of Parliamentary Select Committees convened; pursuant to their findings, various new policy measures were drafted; and the leadership at both the National Gallery and the British Museum got shaken up. So too, the museums' travails prompted debates in the broader and more public art-historical sphere. These debates spun out a set of art-critical writings, including some by Thackeray himself, and behind his wit about the "gin shop" and his glancing account of the "scouring," we can see the real investment—and anxiety-of an art lover.

Yet the museums' trials—so clearly capable of producing diverse imaginative (and sometimes hysterical) responses in the writings of those interested in art history-also clearly had force and relevance for those who were interested in history more broadly construed, and these trials had such bearing in a particular way for Thackeray, now not just as a writer on the arts but as a novelist also. If, as we have seen, the typical would-be writer of historical fiction at mid-century asked, "should I show history," and "if I do, will what I show be false or inauthentic?" then we can see that the museum presented an important and potentially inspiring contrast; it was an institution that said, "show history I must," and then that confined its deliberations to the second of the potential historian's queries alone. Loathe to dispense with history per the dictates of literary fashion, Thackeray could look 
to the National Gallery and the British Museum and find a shared de facto assumption about the necessity of presenting the past; he could, at the same time, find a conversation centered on historical "truth" that, through its sheer focus, seemingly had become richer in terms and subtleties than the parallel one taking place in his own literary domain.

We find ample evidence of the museum's importance as a source of inspiration to Thackeray as would-be historical novelist throughout the whole of the text that surrounds Pendennis's reflections in The Newcomes, and in that novel-which Thackeray wrote after having already established with its predecessor, Henry Esmond, that he would commit to writing historical novels-we find the museum used consistently as part of a subtle examination of the practice of doing more recent history. At the start of the book, Thackeray (now speaking as himself) first proposes: "All types of all characters march through all fables. . . . There may be nothing new under and including the sun"; then immediately after, he counters: "There was once a time when the sun used to shine brighter than it appears to do in this latter half of the nineteenth century" (The Newcomes, I, 4-5). We may discern an earnest truth at the core of this double formulation, not just Thackeray's characteristic irony, and most of us can recognize that we tend to carry within us conflicting recognitions about the way in which history works: we all assume that some things will always look the same as they do for us now, while we acknowledge too that, in the past, things changed. In the remainder of the novel, Thackeray offers up ample evidence for the truth of both sides of this formulation, and the museum becomes a locus for their continuing cross-examination, as, in a series of references to paintings and other works of art, Thackeray reminds readers-his contemporary readers at least-that there is not just affective but also tangible evidence that change and stasis can seem to inhabit a single site.

Indeed, at multiple points in The Newcomes Clive Newcome and his friends and relatives go to the National Gallery and British Museum, and significantly, each of the many times they do so, the works they see are either identifiably the works whose treatment made the museums most controversial in the 184 os and 185 os- the years just after The Newcomes ends-or they are works 
based upon them. A Sebastian canvas that Clive and artist J.J. Ridley delight in, in their youth, for example, would have been treated for worms by the time when readers encountered the young men's exploits. ${ }^{32}$ The "Bacchus and Ariadne" of Titian, which was for them the absolute "best," would become for their followers a locus of controversy-a canvas that "A. G." and "Verax" disputed in 1847 post-cleaning, when the former described it as a "masterpiece of colour,"33 and the latter wrote that it had been disastrously rendered "raw" ("Purchase of the National Gallery," p. 5). The Hogarths that Pendennis invokes to comment on the marriage market ("Have you taken your children to the National Gallery in London, and shown them the Mariage à la Mode?" he apostrophizes to the reader [The Newcomes, I, 301]) - these were the same Hogarths that would be felt, by a Times "Citizen" correspondent of 1844 , to have "quite altered within [his] own recollection," the result of the Gallery's poor management and dirt. ${ }^{34}$ And the "flabby nymphs" of Rubens whom the poor, philistine Colonel fails to love at the National Gallery could be the dancers in Rubens's "Peace and War" (whose fate was shortly to be "disfigured" in the estimation of an "Artist" commentator ["Revival of Vandalism in the National Gallery," p. 8]), while the

\footnotetext{
${ }^{32}$ Clive and his artist friend J. J. Ridley go on a Continental museum tour as young men, and Clive writes to Pendennis: "What a grand thing it is to think of half a mile of pictures at the Louvre! Not but that there are a score under the old pepper-boxes in Trafalgar Square as fine as the best here. . . . There is nothing more grand. Could the pyramids of Egypt or the Colossus of Rhodes be greater than our Sebastian; and for our Bacchus and Ariadne, you cannot beat the best you know. But if we have fine jewels, here are whole sets of them: there are kings and all their splendid courts round about them. J. J. and I must come and live here" (The Newcomes, I, 204). Conservator Seguier testified in $185^{\circ}$, before the Select Committee on the National Gallery, to having treated a Sebastian del Piombo canvas for worms (see Robertson, Sir Charles Eastlake, p. 95).

${ }^{33}$ A. G., "The Spoilt(?) Pictures in the National Gallery," The Times, 4 January 1847 , p. 3. In 1839 , speaking as art critic altar-ego Titmarsh, Thackeray wrote that "before the 'Bacchus and Ariadne,' you may see what the magic of colour is" ([William Makepeace Thackeray], "A Second Lecture on the Fine Arts, by Michael Angelo Titmarsh, Esq.: The Exhibitions," Fraser's Magazine for Town and Country, 19 [1839], 747). Leonée Ormond, comments on the relationships between Clive's responses to art and Thackeray's own (see Ormond, "Thackeray and the "Old Masters," in Translating Life: Studies in Transpositional Aesthetics, ed. Shirley Chew and Alistair Stead [Liverpool: Liverpool Univ. Press, 1999], pp. $235^{-36) \text {. }}$

34 [A Citizen], "The National Gallery: To The Editor," The Times, 30 August 1844, p. 5.
} 
"snuffy brown picture called Titian," which the Colonel cannot admire, was likely not brown for much longer after he saw it (The Newcomes, I, 196). ${ }^{35}$ Life might be timeless and static, or it might be subject to the cruelest of changes, the most random of "barbaric" accidents, all the many, multifaceted abrasions of time's "flaying" or "scouring" passage.

Both things are somehow true at the same time. For many of Thackeray's 185 os readers, the canvases he referred to would, through their cleaning or restoration, have become more "authentic" than they were at the time when an 183 os-era Clive clapped eyes; they would have seemed to shine brightly in the years of The Newcomes's serialization, and as brightly as ever they had. For others, the light would have gone out of these works as surely as the sun dimmed in Thackeray's second formulation, his grim one about the "latter half of the nineteenth century," and Thackeray's merry references to how grand the "Bacchus and Ariadne" looked but fifteen or twenty years ago could only have been painful.

Through a turn to the museum, Thackeray finds a new and usefully ambivalent way in which to consider the questions of historical progress and re-creation that were plaguing (and ultimately discouraging) his literary peers. With a nod to art, he can, on the one hand, still freely indulge what Stephen Bann calls the hope of a "Utopian possibility of a restoration of the past in the context of the present" that his forbearers held out (The Clothing of Clio, p. 138), and share in its indulgence with an art world contemporary like the Art-Journal; he can invest in the shared (if, he admits, possibly fabular) belief that time's march does not necessarily entail loss or destruction. On the other hand, he can suggest that the "latter half of the century" is looking grim, that the developments associated with time will only be negative or "ruin[ous]," and that the possibility of history's revivification is a fallacy. As the restoration of a Titian

\footnotetext{
${ }^{35}$ Clive dispatches Colonel Newcome to both the British Museum and the National Gallery, but sadly, it is only to find the museums' pleasures opaque to him (The Newcomes, I, 196). In addition to the moments cited above, another notable museum allusion occurs when Mrs. Newcome tells Colonel Newcome about her parenting style, and notes her wish that children should have "rational amusements" including trips to the British Museum (The Newcomes, I, 150).
} 
revealed simultaneously "a masterpiece of colour" and a sad "raw" work, depending on who was looking, so the work of history, rather more wholesale, becomes both things under Thackeray's single gaze. And where many present-day literary critics move extra-textually when they try to recuperate a gravity for Thackeray's historical work (in the face of Lukács's sense that Thackeray is always being satirical), mapping The Newcomes's invocations of the museums lets us see full and serious gravity put in dynamic relation with a more giddy energy, and this done within the text itself. ${ }^{36}$

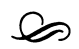

When Thackeray went farther back into history, his interest in questions surrounding the possibility of restoration only got deeper itself, and in turning from the shallower past of The Newcomes to the more distant one of Henry Esmond, we find a departure from the physical location of the museum, but an expanded role for the influence of its language and investigations. From what we have already seen of the contemporary view of the historical novel when Henry Esmond debuted, we can already appreciate the force behind Gordon Ray's suggestion that "Thackeray did not expect Esmond to be popular. He saw it as a risky venture from the beginning" (Thackeray: The Age of Wisdom, p. 175). Now, we can recognize the remarkable extent to which Thackeray uses the language of the gallery to make his evident anxiety manifest in the novel itself. First published in $185^{2}$, Henry Esmond represented Thackeray's boldest effort yet at historical re-animation; the book famously presented itself as a historical transcript-the memoirs, as it announced on its title page, of "A Colonel in the Service of Her Majesty, Q. Anne, Written By Himself"; it proffered itself a historical artifact-at its initial printing, Henry Esmond re-created the look of an eighteenth-century

\footnotetext{
${ }^{36}$ See Lukács, The Historical Novel, p. 202. Avrom Fleishman is one example of an author who makes such an extra-textual turn. He invokes Thackeray's continued return to historical projects as a sign of serious purpose (see Fleishman, The English Historical Novel: Walter Scott to Virginia Woolf [Baltimore: Johns Hopkins Univ. Press, 1971], p. 127).
} 
work, with old-fashioned calf cover and binding, a "mock authentic title page," and an antique typography. ${ }^{37}$ And very soon after the calf-spine was breached and the antiquely printed and titled page turned, the reader would have found a far more sustained meditation than that lodged in The Newcomes on whether such efforts were ultimately useless or no, though he or she would have found that, as in The Newcomes, this was a meditation staged in terms of art.

On the one hand, and initially, it would seem, most dominantly, Henry Esmond pays conspicuous attention to the depredations of age and the tricks of memory; the novel frames these attentions with an artifactual language, and when it performs these acts of attention and locution, it is as if the text acts to forestall criticism that its author might be so naive as really to believe that anything like the real past could be recuperated or successfully represented. In this sense, Thackeray manifestly entertains the belief held by the museum's fiercest critics, and shared by most of his fellow historical novelists, that the project of restoration may be futile, its undertaking foolish. And indeed, at multiple junctures, and particularly through its presentation of its two most "painted" figures, the Dowager and Rachel Castlewood, the novel appears to poke holes in, and fun at, the very prospect of the revivification of things lost in time.

In an exemplary lighter moment, Thackeray brings his hero before the youthful portrait of his now-aged stepmother, the Lady Dowager, and then he indexes the picture to point the way

\footnotetext{
${ }^{37}$ Details about the book's initial appearance are drawn from Bann, The Clothing of Clio, p. 141. For the 1858 reprinting, the book's typography was modernized, and John Sutherland writes: "The consistency of the anachronism amounted to benevolent forgery, and it caused Thackeray chagrin when he first saw Henry Esmond normalized, and his counterfeit undone" (Sutherland, "Introduction," p. 14). Andrew Sanders adds his own spin, and writes that Henry Esmond was "more ambitiously planned than any of Thackeray's preceding novels, and a self-conscious attempt to imitate the style and manner of the fiction of the previous century. It was planned as a unit, and was published in three volumes instead of the monthly parts to which Thackeray and his readers were accustomed. The original format was impressive and contrived to a particular effect; the volumes were printed in old type face, with running titles at the head of each page, and without illustrations. No clearer visual link with Defoe, Fielding and Richardson could have been established" (Andrew Sanders, The Victorian Historical Novel I840-I 880 [London: Macmillan Press, 1978], p. 103).
} 
forward to what must be seen as a comically keyed-but nonetheless negative-consideration of restoration:

Specially, and in the place of honour, was Sir Peter Lely's picture of the Honorable Mistress Isabella Esmond as Diana, in yellow satin, with a bow in her hand and a crescent in her forehead; and dogs frisking about her. . . . and as Goddesses have youth perpetual, this one believed to the day of her death that she never grew older: and always persisted in supposing the picture was still like her. ${ }^{38}$

The Dowager, we are told, believes that she still looks the same as she did decades before, that she is well preserved-but leaving nothing to chance, she is not above the odd (or indeed, the oftemployed) restoring touch. Yet here, black comedy comes in. Henry finds her with her face "illuminated with vermillion, which appeared the brighter from the white paint employed to set it off. She wore the ringlets which had been in fashion in King Charles's time. ... Her eyes gleamed out from the midst of [a] queer structure of paint, dyes, and pomatums" (Henry Esmond, p. 151). Clearly the "picture" that the Dowager instances in the present is not at all "still like" the one that once she did; just as clearly she is blind to the disjuncture. ${ }^{39}$ And ramifying this schism is the frequency with which picture seems to recur to the "venerable personage," prompting her into delusional "nymphic" yearnings and a faulty, artifactually wrought response of attempted selfrenovation, whenever it does. Perpetually we find her "painted" up to the hilt—so, when Henry first meets her: "My Lady Viscountess's face was daubed with white and red up to the eyes, to which the paint gave an unearthly glare" (Henry Esmond, p. 22). Later, when the first Jacobite plot of the novel transpires, a soldier finds her "looking none the less ghastly because of the red which was still on her cheeks and which she could not afford to forego" (p. 43).

\footnotetext{
${ }^{38}$ William Makepeace Thackeray, The History of Henry Esmond, ed. Edgar F. Harden (New York: Garland Publishing, 1989), p. 15o. Further references are to this edition and appear in the text.

39 This scene is, rather strangely, an almost exact duplication for both Esmond and his author of a scene from earlier in the novel, when Henry encounters the same picture, in what are remarkably the same terms-then too, the Dowager "persist[s] in supposing the picture was still like her" (Henry Esmond, p. 150).
} 
Without a sense of art-historical backdrop, the Dowager's resulting self-presentation here can be read, simply, as yet another restaging of what seems to be a very familiar Thackerayan leitmotif - a comic use of the figure of the absurdly "painted" (or repainted) woman. ${ }^{40}$ But it is also possible to read the painted Dowager and her efforts at self-restoration as a more pointed and art-historically conditioned commentary, and this seems to be the mode of reading most strongly promoted by the text.

The Dowager cannot perceive that "a curly wig does not make the old face look young," and she could be marked, accordingly, to act as a walking billboard, warning against the foolhardiness of wrongly rendered or wrongly attempted restorations of what is past. She is clearly "painted" as she is because of an effort to return to what might, by celebrators of the Gallery's cleanings, have been termed her "pristine freshness"-even as, thusly painted, she would seem to resemble nothing so much as the "Tory in Art's" "battered beau," who looks the sad fool for "trying to vie with his great grandson." Through such reading we find another possible scrim beyond The Book of Snobs (1848) against which to set the difficulties of Thackeray's "old beaut[ies]." But through such reading more pertinently, we can discern a larger shape for Thackeray's consideration of how to approach the past, and, too, for how this consideration can seem to be especially laden with pessimism when there is a turn to the museum.

Indeed, in a passage from Henry Esmond that has drawn heavy critical comment, Thackeray himself draws our attention to the commensurate presence of restoration dilemmas alongside his

40 Thackeray reemploys this convention in Henry Esmond's sequel, The Virginians, where Henry's grandson, George Warrington, finds out that Henry's love Beatrix is an old woman in these artifactual terms: “And that was a beauty once!' thinks George Warrington, as his aunt, in her rouge and diamonds, comes in from her rout, 'and that ruin was a splendid palace" (William Makepeace Thackeray, The Virginians, 2 vols. [London: J. M. Dent and Sons, 1961], II, 46). The convention then recurs again in The History of Pendennis, to name but one other exemplary site; in that novel and its own language of "reconstructing" what time has ravaged: "If men sneer . . . at the artifices of an old beauty, at her paint, . . . at those innumerable, and to us unknown, stratagems with which she is said to remedy the ravages of time and reconstruct the charms whereof years have bereft her; the ladies, . . . are not on their side altogether ignorant that men are vain as well" (William Makepeace Thackeray, The History of Pendennis: His Fortunes and Misfortunes, His Friends and His Greatest Enemy, ed. John Sutherland [New York: Oxford Univ. Press, 1994, 1999], p. 455). 
work, and as he does so, he clearly instantiates a rich and specific (but also a grim) connection between visual and verbal arenasseemingly intimating that in neither one is the project of restoration an especially good idea. Henry describes Lady Castlewood's face as it is, marred by smallpox, and he notes that post-illness his benefactress's face is minus "the delicacy of her rosy colour and complexion .... her eyes had lost their brilliancy, her hair fell, and her face looked older." Then he adds very significantly for our purposes: "It was as if a coarse hand had rubbed off the delicate tints of that sweet picture, and brought it, as one has seen unskilful painting-cleaners do, to the dead colour" (Henry Esmond, p. 69). The terms of this depiction transparently reflect a tie to the contemporary debate about pictorial preservation, and in them can be seen not just the realization of Lord Castlewood's worst fears, but also an echo of the anxieties of a Morris Moore or William Coningham. Lady Castlewood is like "Poor Susanna" with her "eyes torn out." Hers is a head resembling the ones from "St. Bavon," with features "effaced" and the "repulsive execresences of badly imitated or diseased flesh" or "white and livid spots" remaining. ${ }^{41}$ And her subsequent efforts to "repaint" herself, or to cover her "fade" with rouge-these efforts are visible failures. Nervously awaiting her Lordship's return, "She put her handkerchief to her eyes and withdrew it laughing hysterically-the cloth was quite red with the rouge when she took it away" (Henry Esmond, p. 72). In fact, her attempts at self-repair are not just unsuccessful when it comes to achieving the aimed at restitution; instead, and pitifully, her attempts actually exacerbate the destruction they were meant to offset. We might be ready to say that through both the Dowager and Rachel-through what is respectively their absurdity and their tragedy-Thackeray can be seen to manifest a real sense of how the present can go wrong in trying to keep in touch with the past, and to manifest a sense, too, that if the present can go so wrong, it seemingly will.

\footnotetext{
${ }^{41}$ Of course, confusingly, sometimes illness was what was attributed to uncleaned pictures by the cleanings's proponents. We have already seen this above in the Art-Journal's suggestion that brown, uncleaned pictures leave their subjects with "flesh tints [that] must either resemble dirty leather or appear covered with brown spots, indicative of a recent virulent corruption."
} 
But then, of course, with Thackeray it is dangerous to be too hasty. In his writings about the museums he could be so sardonic as to be difficult to read; in The Newcomes he presented a series of canvases for the readers to take in with double eyes, and in Henry Esmond too, I will now argue, he turns out to have marked hope as well as pessimism. If Thackeray saw the novel as a "risky" commercial proposition and was skeptical about its chances for commercial success, what he commented on most in his letters and personal papers was a different kind of interest entirely-and across this store of writings more optimism than we have yet seen from him emerges, though he considers still further and related problems of historical resuscitation. In writing to his friend Mrs. Gore, there was obvious anxiety: "there must be a blunder or two or perhaps $20 \mathrm{w}^{\mathrm{h}}$. the critics will spy out"; to Mrs. Scott after its publication, Henry Esmond becomes "a melancholy novel . . . \& a dismal imitation of the old style." ${ }^{22}$ Yet in a note to his secretary, during the novel's composition in February $185^{2}$, there is a request:

Find out

Names of 6 or 8 English and Imperial Officers present at the Siege of Lille.-

The date of the first (the wrong) account of the battle of Wynendale in the London Gazette. 1708.

The date of the Gazette containing the $\operatorname{acc}^{\mathrm{t}}$ of Oudenarde. ${ }^{43}$

To his mother, Thackeray writes with some pride in April 1852: "it takes as much trouble as Macaulays History almost." 44 Then to his daughters Anne and Harriet, he describes visiting Blenheim (a crucial setting in the novel), and his resultant pleasure, as follows:

What I was pleased with was to find that Blenheim was just exactly the place I had figured to myself except that the village is larger,

\footnotetext{
${ }^{42}$ William Makepeace Thackeray, letter to Mrs. Gore, April $185^{2}$, in The Letters and Private Papers of William Makepeace Thackeray, ed. Gordon N. Ray, 4 vols. (Cambridge, Mass.: Harvard Univ. Press, 1946), III, 27; Thackeray, letter to Mrs. Scott, 5 July 1853, in Letters and Private Papers, III, 286.

${ }^{43}$ William Makepeace Thackeray, letter to Eyre Crowe, February? 1852 , in Letters and Private Papers, III, 18.

${ }^{44}$ William Makepeace Thackeray, letter to Mrs. Carmichael-Smyth, 17-19 April $185^{2}$, in Letters and Private Papers, III, 38 .
} 
but I fancy I had actually been there-so like the aspect of it was to what I looked for-and who knows perhaps one does go to places in the spirit-I saw the brook $\mathrm{w}^{\mathrm{h}}$. H. Esmond crossed, and almost the spot where he fell wounded. ${ }^{45}$

In these missives there is a much more open sense of possibility for whether "blunder[s]" will lead to "dismal imitation," or whether "trouble" and diligent inquiry may enable a return "almost [to] the spot" of a long ago day. There is a manifest interest in trying to present history, but also to plunge into it, and as we find Thackeray divided here about his prospects for such undertakings, looking again to the novel reveals an ambivalence there, too, and one lodged most especially in the erotic charge that Rachel commands.

For the Dowager may in fact suggest a hopelessness to the work of the "picture-cleaner," but, importantly, whatever message Rachel offers up, it is a different one-and not just because the younger woman is less aged, or less comical as a figure. ${ }^{46} \mathrm{~A}$ few pages after Rachel's initial post-illness description is given, there is a less critically attended-to passage that seemingly amounts to an act of revision, and in it Henry tells us that Lord Castlewood has fallen out of love with his wife after her illness, but that for him,

his benefactress's sweet face had lost none of its charm.... out of her griefs and cares, as will happen I think when these trials fall upon a kindly heart, and are not too unbearable, grew up a number of thoughts and excellencies which had never come into existence, had not her sorrow and misfortunes engendered them. Sure, occasion is the father of most that is good in us. (Henry Esmond, p. 76)

Rachel's initial dead[ening]" of "colour" becomes a total maintenance of "charms," and the draining off of "sweet[ness]" turns

\footnotetext{
${ }^{45}$ William Makepeace Thackeray, letter to Anne and Harriet Thackeray, 18-20 June $185^{2}$, in Letters and Private Papers, III, 49.

${ }^{46}$ Interestingly, though the Dowager's self-painting, perhaps because repeated, tends to read as more agency-bearing than does Rachel's, both women have suffered the fades or ravages they are trying to compensate for, through no doing of their own. To the extent to which their "defacements" are different, the difference may perhaps be attributed to the distinction between the touch of time and that of "barbaric" illness.
} 
into a full assertion of that quality. Then, many years after her infection and "dead[ening]," we find Rachel seeming strangely even more recovered, and when she is juxtaposed with Beatrix in the midst of the lead-in to the novel's climactic conspiracy plot, the daughter has a "tall beautiful form" but is also "older, paler, and more majestick than in the year before," while "her mother seemed the youngest of the two" (p. 331). For a critic like Elaine Scarry who wants to see Henry Esmond as a rigorously worked-out system of repetitions and slight (calculated) variations, Rachel's changes, and their apparent contradictions, might be construed against a claim like hers that "Thackeray endows a given image with as many disparate connotations as possible, intentionally depriving it of a stable core of meaning" in the interest, according to Scarry, of shoring up the sense that absolute truths, whether "personal" or "objective," are always to be rejected. ${ }^{47}$ For John Sutherland, conversely, Rachel's re-description is important evidence for his larger thesis that Henry Esmond is a work of creative improvisation rather than a work that is carefully planned, and the inconsistency of Rachel's presentation bespeaks what amounts to a lack of (textual) revision. Sutherland asks about Rachel: "Handicapped by these ravages, how does she contrive, eighteen years later, to look younger than her blossoming daughter? The answer may well be that at that early stage Thackeray did not intend to preserve her for a marriage late in life." 48

${ }^{47}$ Elaine Scarry, "The External Referent: History: Untransmissable History in Thackeray's Henry Esmond," rpt. in her Resisting Representation (New York: Oxford Univ. Press, 1994), p. 117. J. Hillis Miller offers another example of a critic who perceives Henry Esmond as a work of great, pre-visioned formal mapping. Interestingly though, he fails to mark the re-brightening that Rachel will seemingly undergo, and his lack of recognition rather destabilizes a crucial juncture of his argument about the book, in which he tries to effect an analog for how he thinks Henry's self-presentation works: "Henry Esmond, one might be tempted to say, is the indirect story or parable of this erasure of Henry's picture of himself and its replacement by another truer picture. The outlines of this other picture gradually emerge for the intelligent interpreter, as the narrative proceeds. The first picture loses its validity and disappears, like Eurydice fading back into the underworld, as Rachel does for Henry when she loses her divine glow" (J. Hillis Miller, Fiction and Repetition: Seven English Novels [Cambridge, Mass.: Harvard Univ. Press, 1982], pp. 103-4).

${ }^{48}$ John Sutherland, "Henry Esmond and the Virtues of Carelessness," Modern Philology, 68 (1971), 348 . 
Working in the artifactual terms that we have been, however, what seems to emerge through Rachel's changes takes on a different aspect, and we must be reminded of the sense of doubled vision lodged in The Newcomes's pages, and latent, in many viewers' eyes, on Victorian museum walls. To our modern ears (or eyes) what first results from the revisions may indeed be a sense of contradiction, and one that must be explained away through recourse either to a principle of instability or to an identification of a careless working style. But to those who read the paper, followed Parliament's debates, or frequented the museum in Thackeray's day, what appeared might have been a perfectly credible and physically familiar kind of recovery-we could think of those Claudes that the Athenceum cited as at first looking "somewhat crude from their cleaning," but that it ultimately predicted would overcome this "temporary injury" and "mellow ... into a better tone than they have possessed within the memory of man" ("New Pictures in the National Gallery," p. 1,398). Or, if what Rachel's changes presented to their first readers was still a contradiction, then at least it was one much more familiarly contained in the "frame" of a single person, one much more apprehensibly lodged in a single portrait.

In a time when any given canvas that had been "restored" could present, depending on your subjective view, either an "absolute ruin" of "coarse" and "dead" effect or a "masterpiece" full of "excellences," Rachel's different appearances hardly seem irreconcilable, or impossible to see simultaneously. ${ }^{49}$ And perhaps the Dowager could be said only ever to have on her the eyes of someone acidly opposed to trying a form of historical return, while Rachel could be seen to get something of a more multifaceted regard-to garner both the lamentations of someone who recognizes the inevitable way in which we are rushed away from what was, and then the optimisms and celebrations of someone

\footnotetext{
${ }^{49}$ This, of course, is just to think of what any given canvas might lodge in a synchronic sense. Looking more diachronically, we could say that any particular Gallery frame could contain three different images on the same canvas-first, an imagined version of a particular picture as it must have been in its "original" condition, on leaving its master's hands; second, a remembered version of the same picture, as it was in the modern day, pre-scouring; and third, a new version of the picture, what it looked like, for better or worse, post-cleaning, with possible "repaintings."
} 
who hopes still for some kind of connection and contact. ${ }^{50}$ The Dowager may suggest that when you try to get to what was, you end up with a bad version of what is, and lose all sense of perspective in the process. Rachel suggests that there might be a form of recuperation or restoration that is ultimately both possible and positive. You still cannot get back to an absolutely original stateher illness changes her appearance, as the cleanings at the gallery did change those pictures they were rendered upon. But it might not be death to try, to extend a hand back into the mists of time. The Dowager would seem a nervous joke at Thackeray's own expense, a figuration of the anxiety he spoke of to friends like Mrs. Scott and Mrs. Gore, in some of his letters about the novel, that all he could manufacture was a "dismal imitation of the old style," and "a blunder of two or perhaps $20 \mathrm{w}^{\mathrm{h}}$. the critics will spy out." Conversely, Rachel would appear on the opposite side of the spectrum, a sign of hope, a manifestation of a sense in Thackeray that what he was doing could prove "very grand" after all, and an embodied version of the idea that it might be possible to return in some meaningful way from the present to the past, which latter place, as he wrote, again to his mother, could turn out to "occup[y] [him] to the exclusion of the $19^{\text {th }}$ century pretty well." ${ }^{51}$ The historical novel could still have life in it; the museum, full of ruins and relics, offers conceptual and linguistic supports for asserting as much.

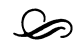

Certainly, for his Victorian critics, Thackeray had done something significant around history, and something related to art in his efforts to revivify the historical novel, and in closing I pick up their language as I highlight how much

\footnotetext{
${ }^{50}$ When Henry returns to Castlewood on a holiday from University, he finds the love between Lord and Lady Castlewood extinguished and marks his finding in these terms: "After the illumination, when the love-lamp is put out that anon we spoke of, and by the common daylight you look at the picture, what a daub it looks!" (Henry Esmond, p. 93). Rachel's reverse change from "daub" to "picture," in Henry's ultimate account of her, would seem much helped along by the opposite effect, precisely by what amounts to her "illumination" via his incandescent and restoring brush.

${ }^{51}$ William Makepeace Thackeray, letter to Mrs. Carmichael-Smyth, 26 February 1852, in Letters and Private Papers, III, 15.
} 
it confirms not only Thackeray's connections to the museums' debates, but also the centrality of those debates to a larger Victorian culture's historical considerations. For to Thackeray's critics, the novel's efforts at "restoring" the "pristine freshness" of Queen Anne's Day became contiguous with the museums' conservation dilemmas, and as Thackeray's gesture toward revivifying the past invited a transposition between themselves and the museums' own efforts, his first reviewers made this transposition consistently. Thackeray was seen as having joined the museum in trying to reach a mass audience, and to perform for this audience's interest in some form of "national heritage," and he was appraised accordingly. In the Spectator, George Brimley appreciated that Thackeray had "triumphed over" the "rock" faced by lesser historical novelists: "the danger of reproducing too much of their raw material; making the art visible by which they construct their image of a bygone time; painting its manners ..." too anachronistically. He announced that Thackeray had produced a great work indeed: "Queen Anne's Colonel writes his life ... just as such a Queen Anne's Colonel might be supposed to have written it." ${ }^{22}$ On the other side of the critical divide we find Ainsworth, who praised Thackeray for his "closest observance of the habits of the period," but who rued, ultimately, that "Mr. Thackeray has wielded the pen of the satirist so long and so effectively that he appears never wholly satisfied until he has marred the beauty of his own bright pictures by laying bare the canvas on which they are painted, and showing the tricks and artifices by which it is daubed" ("Esmond and Some Other Novels," p. 484). Or there is then the reviewer in The United States Review: "When Mr. Thackeray paints historical pictures, the world will not at all thank him for distorting his figures, for heightening their occasional deformities and exposing their sores." 53

But in each of these cases what we will discover is the same essential phenomenon: though at other points in their reviews Henry Esmond's critics may consider any number of facets of Thackeray's writings, as they address larger issues of historical fidelity and perspective they employ vocabulary that we have seen

\footnotetext{
${ }^{52}$ [George Brimley], “Thackeray's Esmond," Spectator, 6 November 1852, p. 1,o66.

53 [Anon.], "Thackeray" [rev. of Henry Esmond], The United States Review, 1 (1853), $25^{1 .}$
} 
associated with curation, collection, and display in Thackeray's art-historical sphere. Their vocabulary is one of "art conceal[ing] art" like the best work of the restorer's brush, of figures "distort[ed]," their "sores" "expos[ed]"-ironically through too zealous an effort to show them clearly. Thackeray, like the site of the museum, is either praised for his restoration of something like "pristine freshness" or is held negatively accountable for his would-be stewardship of the national past-of those elements thereof whose "deformities" he heightens. Language that seems familiar from discussions of how best to deal with art works transmitted through the historical past gets translated into a discussion of which artistic terms history finds its most appropriate transmission in. And if the historical novel is to be a viable form, it seems, novelists like Thackeray would do well to keep in mind the adage of the art world's "Tory" that "the future character" of the past's image "depends upon his (the cleaner's) eye" ("National Gallery: To the Editor," p. 3); the success of the genre depends on a steady hand and a brush wielded just right.

\section{California Institute of Technology}

\section{ABSTRACT}

Dehn Gilmore, "The Difficulty of Historical Work in the NineteenthCentury Museum and the Thackeray Novel" (pp. 29-57)

This essay suggests that conservation debates occasioned by the democratization of the nineteenth-century museum had an important impact on William Makepeace Thackeray's reimagination of the historical novel. Both the museum and the historical novel had traditionally made it their mission to present the past to an ever-widening public, and thus necessarily to preserve it. But in the middle of the nineteenth century, the museum and the novel also shared the experience of seeming to endanger precisely what they sought to protect, and as they tried to choose how aggressive to be in their conserving measures, they had to deliberate about the costs and benefits of going after the full reconstruction (the novel) or restoration (the museum) of what once had been. The first part of this essay shows how people fretted about the relation of conservation, destruction, and national identity at the museum, in The Times and in special Parliamentary sessions alike; the second part of the essay traces how Thackeray drew on the resulting debates in novels including The Newcomes (1853-55) and The History of Henry Esmond (1852), as he looked for a way to revivify the historical novel after it had gone out of fashion. He invoked broken statues and badly restored pictures as he navigated his own worries that he might be doing history all wrong, and damaging its shape in the process.

Keywords: William Makepeace Thackeray; Historical Novel; Museum; History of Henry Esmond; National Gallery 


\section{Contributors to this Issue}

Tris H FE R G U S O n teaches in the Department of English at Liverpool Hope University. She is the author of "Trial and Error in Thomas Hardy's Legal Fictions," which appeared in the Thomas Hardy Joumal in 2008. Her essay "Memoirs and Recollections" is forthcoming in Thomas Hardy in Context, edited by Phillip Mallet, which will be published by Cambridge University Press in 2012.

Dehn Gilmore, Assistant Professor of English at the California Institute of Technology, is the author of "Terms of Art: Reading the Dickensian Gallery," which appeared in Dickens Studies Annual in 2011. She is currently completing a book manuscript tentatively titled "Forms of Regard: The Victorian Novel and the Space of Art."

M I C H E L L E K O H L E R, Assistant Professor of English at Tulane University, has published two essays in the Emily Dickinson Journal (with another forthcoming) on Dickinson's engagement with mid-nineteenth-century cultural discourses, as well as two essays, in Chaucer Review and American Literary Realism, on the relationship of visual perception to literary form (with another forthcoming in Arizona Quarterly). She is now completing a book on nineteenth-century American unrest about the figural relationship between vision, writing, and literary form, particularly in the wake of Transcendentalist theories of poetic language.

C A s i L E G e t t e is Assistant Professor of English in the Department of English at the University of Georgia. She is a recipient of the Proquest Distinguished Dissertation Award, University of Michigan, 2011 , and is currently working on a book-length project tentatively titled "The Past Jumps Up: British Radicals and the Remaking of Literary History, 1790-1870."

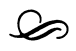


Reproduced with permission of the copyright owner. Further reproduction prohibited without permission. 